\title{
Parental Perspectives on Storybook Reading in Indian Home Contexts
}

\author{
Pooja Pandith ${ }^{1} \cdot$ Sunila John ${ }^{1}\left(\mathbb{0} \cdot\right.$ Monica L. Bellon-Harn ${ }^{2} \mathbb{D} \cdot$ Vinaya Manchaiah ${ }^{2} \mathbb{C}$
}

Accepted: 19 December 2020 / Published online: 7 February 2021

(c) The Author(s) 2021

\begin{abstract}
The benefits of parent-child storybook reading experiences in the home are well documented. However, there is a dearth of information regarding parent-child storybook reading experiences in Indian home contexts. This study investigated parental perspectives towards storybook reading in the Indian context among 100 parents of typically developing preschool children. In this questionnaire-based study, parental responses were collected and the patterns of reading exposure, child's interest in reading, storybook reading practices, and attitudes \& beliefs towards storybook reading were reported using descriptive statistics. Correlation between demographic variables (i.e., child's age and socioeconomic status) and storybook reading domains were explored. The majority of parents initiated storybook reading with their children at 2 years of age or older. Parents read to their children one to two times per week for $10 \mathrm{~min}$ and had fewer than 10 books in the home. Parents reported that their children were interested in storybook reading and reported the use of quality storybook reading practices. Homes characterized with higher socioeconomic status included more quality home literacy environment factors, although socioeconomic status did not correlate with the parental beliefs and attitudes towards reading. Results provide preliminary information regarding parental perspectives on storybook reading in Indian home contexts and point toward socioeconomic and sociocultural variation in home literacy environments. Understanding more about the parental interactions surrounding storybook reading will facilitate the development of parent programs to enhance and promote quality home literacy environment in Indian home contexts.
\end{abstract}

Keywords Storybook reading $\cdot$ Preschool children $\cdot$ Reading exposure $\cdot$ Reading interest $\cdot$ Reading practices $\cdot$ Attitudes and beliefs

\section{Introduction}

Robust findings indicate that the home literacy environment (HLE) is associated with the acquisition of language and literacy across sociocultural contexts (e.g., Bus et al. 2000; Mol et al. 2008). The HLE refers to the literacy resources and activities advanced by family members and parent attitudes and beliefs about literacy (Niklas et al. 2020). HLE factors such as children's age and frequency of exposure to storybook reading are important predictors of children's language and literacy development (Mol and Bus 2011; Niklas

Sunila John

sunila.john@manipal.edu

1 Department of Speech \& Hearing, Manipal College of Health Professions, Manipal Academy of Higher Education, Manipal, India

2 Department of Speech and Hearing Sciences, Lamar University, Beaumont, TX, USA et al. 2016). Parents who engage their young children in frequent storybook reading promote their children's interest in storybooks, which may exploit the impact on later literacy and language development (Bracken and Fischel 2008; Scarborough and Dobrich 1994; Zhou and Salili 2008). In turn, the relationship may be reciprocal in that children's interest may trigger parents' interest and contribute to an enriched HLE (Pezoa et al. 2019).

Parent engagement in storybook reading is linked to parental attitudes and beliefs about reading. If parents have positive reading attitudes and beliefs, they will be more likely to engage in storybook reading activities (Bingham 2007; Sénéchal and LeFevre 2002). Weigel et al. (2006) described parents as either facilitative or conventional, based on their beliefs on their role in the development of literacy. Facilitative parents, as opposed to conventional, play a dynamic role in educating children at home with a literacy enriching environment. The more self-efficacy parents have in their role facilitating their children's literacy, the 
higher the quality of their storybook reading (Newland et al. 2011). Parents who perceive that their actions contribute to their children's language and literacy are more likely to be motivated to be involved in storybook reading (Bojczyk et al. 2016).

Central to the positive impact of storybook reading experiences is the quality of interactions that occur. Parent behaviors such as directing attention, clarifying information, expanding on their children's utterances, providing feedback, and asking wh-questions are among behaviors that contribute to high-quality storybook reading experiences (Chang and Luo 2020; Neuman 1996; Ninio and Bruner 1978). Parents' use of print referencing behaviors, such as talking about the print form and characteristics in the storybook, also promote the quality of parent-child interactions during storybook reading (Justice and Ezell 2000).

\section{HLE, Socioeconomic Status, and Sociocultural Variation}

Socioeconomic status (SES), as indicated by parent occupation, income, and education, is associated with the HLE. Lower SES is linked to a less enriched HLE in that access to literacy resources and quality storybook reading may be limited (Kluczniok et al. 2013). This relationship is frequently reported across various sociocultural contexts (e.g., Bus et al. 2000; Neumann 2016; Niklas et al. 2016; O'Farrelly et al. 2018; Raikes et al. 2006). That said, HLE factors vary within groups of similar SES (Christian et al. 1998). For example, Gottfried et al. (2015) determined that the frequency of storybook reading independently predicted later reading ability when maternal education was controlled. Niklas et al. (2016) reported that early exposure to storybook reading was an important predictor of language and literacy independent of SES or child's dominant language. To date, few studies have examined the HLE in Indian homes. In light of the universal call for quality literacy experiences in the home to mitigate against later language, literacy, and academic challenges (High et al. 2014), more research is needed to understand the HLE in Indian contexts. Additionally, the relationship between the HLE and SES should be examined to understand the nature of the association.

\section{HLE in Indian Contexts}

In India, as per Census data (2011), there are 158.8 million children ( $13.12 \%$ of total population) in the age range of 3-6 years making it crucial to ensure provision of quality language and literacy exposure for young children. Of the few studies examining the HLE in Indian homes, three examined children's exposure to literacy activities. Kalia (2007) examined bilingual children's $(n=24)$ exposure to storybook reading in home environments who were enrolled in two preschools in Bangalore, India. Exposure was determined by calculating the number of trips to the library and completing the Children's Titles Checklist-CTC (Sénéchal et al. 1996). Parents reported that they did not frequently visit a library, had approximately 22 books at home, and engaged in storybook reading with their children approximately three times per week. A relationship between exposure to storybooks based on the CTC and children's narrative complexity, syntactic complexity, phonological awareness (i.e., blending and elision) skills, and knowledge of concepts about print was reported. Based on their study among 145 kindergarten children from a low-income community in Mumbai, India, Kalia and Vagh (2008) reported wide variation in the HLE in contrast to a middle-income community in Bangalore. While $95 \%$ of the parents from the middleincome community reported about their children initiating storybook reading, $86 \%$ of the parents from the low-income community reported children engaging with books. Significant correlations between the number of children's books, frequency of shared reading, and frequency of book borrowings from classroom and community libraries were noted in the Mumbai sample. The parents reported that they set aside homework time focusing on teaching print-related concepts at home rather than shared reading. In a later study, Kalia and Reese (2009) surveyed fifty parents of kindergarten children from a public-school setting in Bangalore, India regarding their HLE. Parents reported that children had between 0 and 40 books at home and were read to two to three times per week. HLE as measured by the CTC for India scores, number of books, and frequency of book reading were correlated with maternal education in that mothers who were more educated read more frequently to their children and were aware of popular titles of children's books.

Consistent with previous research, a rich HLE is linked to positive language and literacy skills in children and indicators of SES (i.e., education) appear to be associated with HLE factors. However, the small sample size in these studies limit generalization of the findings. Additionally, India is a diverse country with diverse sociocultural influences. In many Indian communities, the oral tradition of storytelling is prominent with children growing up listening to stories from elders in the family and community rather than the literacy experiences through books (Buvaneswari and Padakannaya 2017; Kalia and Vagh 2008; Khurana and Rao 2011). Khurana and Rao (2011) reported that among 140 parents of preschool children from Mysore, India, parents preferred story telling over story reading, irrespective of parental education level. A recent position paper on early language and literacy in Indian context by the Centre for Early Childhood Education and Development (CECED) and CARE India (2016) also documented that shared book reading is not a culturally familiar routine. Further, the early childhood settings such as playschools often serve as a safe environment 
for children of working parents and provide nutrition rather than a haven for language and literacy stimulation (Kaul et al. 2017). Due to a lack of focus on literacy activities in the early years, in many instances, children are exposed to a print environment only during the formal instruction at the kindergarten level.

The observations from many recent educational outcome reports further illustrates the grave concern regarding children being at risk or growing up with literacy deficits. For instance, the Assessment and Evaluation Reports (2019) indicated that only $53.4 \%$ of the surveyed 8 -year old children in class III could read the class I level text. The Planning Commission evaluation report on the Sarva Shiksha Abhiyan (2010) documented that $58 \%$ of the surveyed second grade children had difficulty reading letters. The nature of literacy exposure and practices followed in Indian contexts necessitates more research to understand the HLE in Indian homes as well as the association with SES (Buvaneswari and Padakannaya 2017; Khurana and Rao 2011; Sharma and Saini 2000).

\section{Study Purpose}

This study examines HLE factors in the Udupi district in Karnataka in southwest India. As per the Census 2011 data, the child population, between birth to 6 years of age, in Udupi is 103,160 (52, 689 males, 50, 471 females), which accounts for $8.8 \%$ of the overall population. This study extends previous studies by examining: (1) exposure variables in a region of India not yet described in the literature; (2) Indian parental practices, beliefs and attitudes toward storybook reading not yet described in the literature; and (3) the association of SES and child's age with HLE factors. A parent survey was used to describe children's age and frequency of exposure to storybook reading, children's interest in reading in the home, storybook reading practices and parental attitudes and beliefs about reading in the home. Relationships between SES with children's age and frequency of exposure, children's interest in reading, and parental storybook reading practice, attitudes, and beliefs were examined.

\section{Method}

A cross sectional study design was employed for the present study. Approval for this research was obtained from the Institutional Research Committee (IRC) and Institutional Ethics Committee (IEC-229/2019) following which the Clinical Trial Registry India (CTRI) approval (CTRI/2019/05/019439).

\section{Participants}

Parents of preschool children were recruited from home environments and social gathering places (e.g., park) within Udupi district in South Karnataka, India through convenience sampling. Parents of children with typical speech, language, sensory and motor development, and parents who had at least 10 years of schooling were included. The child's development in each of these domains was assessed by the first author using an informal screening questionnaire. Parents who reported children having any speech and language delays, neurological disorders, hearing/visual impairment, cognitive or linguistic delay, and those parents with health-related issues were excluded. The first author recruited the parents. Written informed consent was obtained from parents meeting the inclusion criteria. Following consent, the first author verbally asked the questions on the survey and marked the responses.

A total of 100 parents, aged between 23 and 44 years (average age: 32.7 years), were surveyed (i.e., 89 mothers, 11 fathers). A majority of mothers (i.e., 59\%) and fathers (i.e., 99\%) were employed. A majority of mothers completed graduate and post-graduate work (i.e., 63\%). Fifteen percent of mothers completed 10 years of education, and $22 \%$ completed 12 years. Forty-seven percent of fathers completed graduate or post-graduate education, $20 \%$ completed 12 years of education, and $32 \%$ completed 10 years. Children ranged in age from 3 to 5 years of age, with a mean age of 4 years. Sixty-four of the families included one child, 29 included two children, and one family included three children. Languages spoken in the home included Tulu (33\%), Kannada (27\%), Konkani (25\%), Marathi (10\%), and Malayalam (2\%). Urdu, Telugu, and Tamil were spoken in $1 \%$ of the homes.

Socioeconomic status (SES) was determined using the Modified Kuppuswamy Socioeconomic Scale (Saleem 2019). Status is determined based on points attributed to the education level of the head of the family, occupation status of the head of the family, and total family income. Total scores range from 3 to 29, with higher score indicating higher SES. Families are categorized into five different socioeconomic strata: upper $(I=26-29)$, upper middle (II = 16-25), lower middle (III = 11-15), upper lower $(\mathrm{IV}=5-10)$ and lower $(\mathrm{V}=4-3)$. This scale is commonly used in hospital and community-based studies (Saleem 2019). Of the parents in this sample, $4 \%$ were categorized as upper, $42 \%$ were categorized as upper middle, $39 \%$ were categorized as lower middle SES, and $15 \%$ were categorized as upper lower. 


\section{Survey}

Researchers developed four survey domains based on research aims: (1) children's exposure to reading; (2) children's interest in reading; (3) parental storybook reading practices; and (4) parental attitude and beliefs about storybook reading.

\section{Content Validity}

DeVellis (2016) opined that the item selection for multiple domains must consider both the content diversity and internal consistency reliability. If the selection of items is limited to internal consistency reliability criteria, it could reduce content diversity. This survey identified items within the four domains while remaining short enough to ensure completion. Robust peer-reviewed publications provided the source for items related to each domain (e.g., Buvaneswari and Padakannaya 2017; DeBaryshe and Binder 1994; DeBruin-Parecki 1999; Kalia 2007). Once items were identified within domains, the investigator and two experienced speech-language pathologists ( $>12$ years of experience) individually analyzed each item for the appropriateness, clarity, representativeness, choice of words and meaning to the specified domain. Items that were deemed valid by all the three investigators were considered for the study questionnaire. The items were then verified in terms of readability using the Flesch-Kincaid Grade Level Formula (F-KGL). The text of this questionnaire was ranked at level 5, which means it was accessible to the general population.

For questionnaire content and scoring criteria validation, input from five speech-language pathologists and five preschool teachers with minimum of 5 years of involvement in working with preschool children was considered. The experts were asked to mark each question as appropriate, inappropriate, or needs modification. Each item in the questionnaire was evaluated individually to decide whether to retain, modify, or delete the items. Only those items which were deemed valid by all the investigators were considered for the study questionnaire. The survey was field tested with parents $(n=32)$ of young typically developing children below 5 years of age to ensure the questions were understandable to parents (unpublished data). Once the validation and modification process was completed, both Kannada and English version of the final questionnaire was made available for the study.

Internal consistency, the reliability within the questionnaire, was measured using Cronbach's alpha. Cronbach's alpha of 0.7 or higher is considered as acceptable internal consistency. The Cronbach's alpha was found to be 0.87 for child's interest in reading, indicating good internal consistency. The Cronbach's alpha was found to be 0.78 for storybook reading practices. However, a slightly lower
Cronbach's alpha of 0.67 was noted for parental attitude and beliefs about storybook reading.

\section{Data Analysis}

Descriptive statistics were obtained using SPSS v.17. The corrected item-total correlation was completed to check the correlation between each item within the section. Relationships between SES and HLE variables of interest were tested using Spearman's correlation as it involved ordinal scale measurements and the data was not normally distributed. For the purpose of correlation testing, SES was treated as a continuous variable based on total score on the Modified Kuppuswamy Socioeconomic Scale. Based on the Spearman's correlation coefficient value $\left(r_{s}\right)$, the strength of correlation was considered to be 'very weak' (0.00-0.19), 'weak' (0.20-0.39), 'moderate' (0.40-0.59), 'strong (0.60-0.79) and 'very strong' $(0.80-1.0)$.

\section{Results}

\section{Children's Age and Frequency of Exposure}

As indicated in Table 1, 47\% of parents reported that they started reading to their child at 3-4 years of age, while $42 \%$ reported reading to their child at 2-3 years of age. Thirtyeight percent of parents reported that they had read books within the past few days, and 22\% reported that they read books to their children a month ago. Sixty-one percent of the parents reported reading at least 1-2 times per week, and $47 \%$ of parents reported that they spent up to $10 \mathrm{~min}$ per day reading with their children. Picture books (77\%) and short storybooks (64\%) were the most commonly preferred books, with $86 \%$ of families having fewer than 10 children books in the home.

\section{Child's Interest in Reading}

Table 2 depicts the parental perception on their child's interest in reading based on nine questions. A majority of parents reported that their children very often or often asked questions if the story was not clear (i.e., 58\%) and maintained interest during stories (i.e., 70\%). A majority of parents reported their children sometimes looked at books on their own (i.e., 50\%), were able to understand stories read to them (i.e., 49\%), repeated back new words (i.e., 57\%), asked parents to read a book to them (i.e., $51 \%$ ), made comments during book reading (i.e., $52 \%$ ), and attempted to read along (i.e., 51\%). The least reported behavior was their children's ability to guess what happened next in a story (i.e., never $=55 \%$ ). 
Table 1 Parental report on age and frequency of exposure to reading
How old was your child when you started reading storybooks to him/
her?

When was the last time you read a book with your child?

How often do you read to your child in a week?

How often do you read to your child in a day?

Types of books you prefer to read to your child

How many children's books do you have in your house?

$\begin{array}{ll}<1 \text { year } & 1 \\ \text { 1-2 years } & 10 \\ \text { 2-3 years } & 42 \\ \text { 3-4 years } & 47 \\ \text { Yesterday } & 28 \\ \text { A few days ago } & 38 \\ \text { A week ago } & 12 \\ \text { A month ago } & 22 \\ \text { Never } & 1 \\ \text { 1-2 times/week } & 61 \\ 3-5 \text { times/week } & 19 \\ 6-7 \text { times/week } & 19 \\ <5 \text { min/day } & 20 \\ 10 \text { min/day } & 47 \\ 30 \text { min/day } & 28 \\ >60 \text { min/day } & 5 \\ \text { Short storybooks } & 64 \\ \text { Picture books } & 77 \\ \text { Fables/folktales/moral stories } & 27 \\ \text { Religious books } & 5 \\ \text { None } & 1 \\ <10 \text { books } & 86 \\ <20 \text { books } & 9 \\ >20 \text { books } & 4\end{array}$

Table 2 Parents report on child's interest in reading

\begin{tabular}{|c|c|c|c|c|c|c|c|c|}
\hline Questions & Never $(\%)$ & $\begin{array}{l}\text { Some- } \\
\text { times } \\
(\%)\end{array}$ & Often $(\%)$ & Very often $(\%)$ & Mean (SD) & Median & Mode & $\begin{array}{l}\text { Corrected item- } \\
\text { total correlation }\end{array}$ \\
\hline $\begin{array}{l}\text { How often does your child look at books on } \\
\text { his/her own? }\end{array}$ & 4 & 50 & 23 & 23 & $2.65(0.88)$ & 2 & 2 & 0.651 \\
\hline $\begin{array}{l}\text { How often does your child ask you to read to } \\
\text { him/her? }\end{array}$ & 13 & 51 & 16 & 20 & $2.43(0.95)$ & 2 & 2 & 0.741 \\
\hline $\begin{array}{l}\text { How often does your child maintain interest } \\
\text { during reading stories? }\end{array}$ & 1 & 29 & 37 & 33 & $3.02(0.81)$ & 3 & 3 & 0.675 \\
\hline $\begin{array}{l}\text { How often does your child ask questions if } \\
\text { the story is not clear? }\end{array}$ & 8 & 34 & 19 & 39 & $2.89(1.02)$ & 3 & 4 & 0.576 \\
\hline $\begin{array}{l}\text { How often does your child repeat back the } \\
\text { new words heard while reading? }\end{array}$ & 8 & 57 & 19 & 16 & $2.43(0.85)$ & 2 & 2 & 0.632 \\
\hline $\begin{array}{l}\text { How often does your child attempt to read } \\
\text { along with you while reading it to them? }\end{array}$ & 20 & 51 & 19 & 10 & $2.19(0.87)$ & 2 & 2 & 0.582 \\
\hline $\begin{array}{l}\text { How often does your child make comments } \\
\text { while story is being read to them? }\end{array}$ & 12 & 52 & 18 & 18 & $2.42(0.92)$ & 2 & 2 & 0.699 \\
\hline $\begin{array}{l}\text { How often do you think your child is able to } \\
\text { understand the story read to him/her? }\end{array}$ & 5 & 49 & 27 & 19 & $2.60(0.85)$ & 2 & 2 & 0.542 \\
\hline $\begin{array}{l}\text { How often your child is able to guess what } \\
\text { will happen next in the story based on } \\
\text { pictures? }\end{array}$ & 55 & 34 & 5 & 6 & $1.62(0.83)$ & 1 & 1 & 0.342 \\
\hline Total score & & & \multicolumn{6}{|c|}{ Mean (SD)/Average score: 22.25 out of total score of 36} \\
\hline Cronbach's alpha & & & 0.869 & & & & & \\
\hline
\end{tabular}

A score of $1=$ Never, a score of $2=$ Sometimes, a score of $3=$ Often, a score of $4=$ Very Often. Scores for this sub-section could range from 9 to 36 
Table 3 Parents storybook reading practice

\begin{tabular}{|c|c|c|c|c|c|c|c|c|}
\hline Questions & Never (\%) & Sometimes (\%) & Often (\%) & Very often $(\%)$ & Mean (SD) & Median & Mode & $\begin{array}{l}\text { Corrected item- } \\
\text { total correlation }\end{array}$ \\
\hline $\begin{array}{l}\text { How often do you name pictures in } \\
\text { books and talk about the picture? }\end{array}$ & 1 & 30 & 30 & 39 & $3.07(0.85)$ & 3 & 4 & 0.568 \\
\hline $\begin{array}{l}\text { How often do you try to make the } \\
\text { story more real to your child by } \\
\text { relating the story to his/her life? }\end{array}$ & 23 & 33 & 14 & 30 & $2.51(1.15)$ & 2 & 2 & 0.631 \\
\hline $\begin{array}{l}\text { How often do you change your voice } \\
\text { to suit the characters when you read } \\
\text { to your child? }\end{array}$ & 24 & 38 & 16 & 22 & $2.36(1.07)$ & 2 & 2 & 0.436 \\
\hline $\begin{array}{l}\text { How often do you point your child's } \\
\text { fingers to words/letters/related pic- } \\
\text { tures when you both read? }\end{array}$ & 3 & 38 & 24 & 35 & $2.91(0.92)$ & 3 & 2 & 0.434 \\
\hline $\begin{array}{l}\text { How often do you ask questions to } \\
\text { your child during story reading? }\end{array}$ & 9 & 33 & 21 & 37 & $2.86(1.02)$ & 3 & 4 & 0.384 \\
\hline $\begin{array}{l}\text { How often do you ask your child to } \\
\text { repeat back the story according to } \\
\text { what the child has understood? }\end{array}$ & 40 & 42 & 9 & 9 & $1.87(0.91)$ & 2 & 2 & 0.560 \\
\hline $\begin{array}{l}\text { How often do you make your own } \\
\text { story and tell your child? }\end{array}$ & 35 & 33 & 7 & 25 & $2.22(1.17)$ & 2 & 1 & 0.418 \\
\hline $\begin{array}{l}\text { How often do you encourage your } \\
\text { child to make his/her own story? }\end{array}$ & 65 & 18 & 7 & 10 & $1.62(0.99)$ & 1 & 1 & 0.436 \\
\hline Total score & & & \multirow{2}{*}{\multicolumn{6}{|c|}{ Mean (SD)/Average score: 19.42 out of total score of 32}} \\
\hline Cronbach's alpha & & & & & & & & \\
\hline
\end{tabular}

A score of $1=$ Never, a score of $2=$ Sometimes, a score of $3=$ Often, a score of $4=$ Very Often. Scores for this sub-section could range from 8 to 32

\section{Parent Storybook Reading Practices}

As indicated in Table 3, the majority of parents reported that they often or very often named and talked about pictures (i.e., 69\%), pointed their children's fingers to pictures, words, or letters (i.e., 59\%), and asked questions (i.e., 58\%). Less common practices included relating the story to their children's life, changing their voice to suit the characters, making up their own stories and telling them to their child, and asking for repetition from their child. A majority of parents reported to never encourage their child to make up their own story (i.e., $65 \%$ ).

\section{Parent Attitudes and Beliefs About Storybook Reading}

As indicated in Table 4, the majority of parents disagreed or strongly disagreed that their child is too young to learn about reading (i.e., 89\%), language is inherited (i.e., 72\%), they discipline their child to make them read (i.e., 70\%), they are too busy or too tired to read to their child (i.e., 76\%), their child will not sit still when reading (i.e., $81 \%$ ), and they finding book reading boring or difficult (i.e., 85\%). A majority of parents agreed or strongly agreed that they read to their child whenever their child asked (i.e., $85 \%$ ), they have good memories of reading as a child (i.e., 92\%), and they enjoyed reading storybooks with their child (i.e., 99\%). Parents strongly agreed or agreed that they were the ones who are involved in developing a broad interest in reading in their child (i.e., 97\%) and reading at home helped their child perform well at reading words in school (i.e., 97\%). They also agreed that storybook reading at home would help the child in terms of various skills such as grasping new words, thinking, understanding and learning moral values (i.e., $98 \%$ ).

\section{Correlation of HLE Variables with SES and Child's Age}

Table 5 illustrates the correlation between SES, child's age, and exposure variables (age of exposure, frequency of exposure and composite scores for child's interest, parent reading practices and parent attitude and beliefs). The SES was found to have a moderate positive correlation with parent reading practices $\left(r_{s}=0.42, p<0.01\right)$, and a weak but positive correlation with number of books read per week $\left(r_{s}=0.24\right.$, $p<0.05)$, and child's interest in reading $\left(r_{s}=0.25, p<0.05\right)$. Also, there was a weak negative correlation between SES and the age of exposure $\left(r_{s}=0.24, p<0.05\right)$. With reference to the children's age, among the HLE variables, a moderate but positive correlation was noted with child's interest in reading $\left(r_{s}=0.47, p<0.01\right)$ and number of books read per 
Table 4 Parents attitude and beliefs about storybook reading

\begin{tabular}{|c|c|c|c|c|c|c|c|c|}
\hline Questions & Strongly agree & Agree & Disagree & $\begin{array}{l}\text { Strongly } \\
\text { disagree }\end{array}$ & Mean (SD) & Median & Mode & $\begin{array}{l}\text { Corrected item- } \\
\text { Total correlation }\end{array}$ \\
\hline $\begin{array}{l}\text { I have good memories of being read to when I } \\
\text { was a child }\end{array}$ & 31 & 61 & 8 & - & $1.77(0.58)$ & 2 & 2 & 0.251 \\
\hline I enjoy reading storybooks with my child & 53 & 46 & 1 & - & $1.48(0.52)$ & 1 & 1 & 0.555 \\
\hline $\begin{array}{l}\text { I read storybooks to my child whenever he or she } \\
\text { wants }\end{array}$ & 22 & 63 & 14 & 1 & $1.94(0.63)$ & 2 & 2 & 0.482 \\
\hline $\begin{array}{l}\text { Schools are responsible for teaching children } \\
\text { storybook reading and not parents }\end{array}$ & 1 & 7 & 46 & 46 & $1.63(0.66)$ & 2 & 1 & 0.413 \\
\hline $\begin{array}{l}\text { I find it boring or difficult to read storybooks to } \\
\text { my child }\end{array}$ & 2 & 13 & 70 & 15 & $2.02(0.60)$ & 2 & 2 & 0.407 \\
\hline $\begin{array}{l}\text { I have to scold or discipline my child when we try } \\
\text { to read storybooks }\end{array}$ & 2 & 28 & 60 & 10 & $2.22(0.64)$ & 2 & 2 & 0.317 \\
\hline $\begin{array}{l}\text { I don't read storybooks to my child because he or } \\
\text { she won't sit still }\end{array}$ & 2 & 17 & 67 & 14 & $2.07(0.62)$ & 2 & 2 & 0.343 \\
\hline My child is too young to learn about reading & 1 & 10 & 68 & 21 & $3.09(0.58)$ & 3 & 3 & 0.610 \\
\hline $\begin{array}{l}\text { Even if I would like to, I'm just too busy or too } \\
\text { tired to read storybooks to my child }\end{array}$ & 1 & 23 & 59 & 17 & $2.08(0.66)$ & 2 & 2 & 0.384 \\
\hline $\begin{array}{l}\text { I don't read storybooks to my child because there } \\
\text { is no quiet place in the house }\end{array}$ & 1 & 3 & 65 & 31 & $1.74(0.56)$ & 2 & 2 & 0.511 \\
\hline $\begin{array}{l}\text { I don't read storybooks to my child because I } \\
\text { have other, more important things to do as a } \\
\text { parent }\end{array}$ & 1 & 11 & 65 & 23 & $1.90(0.61)$ & 2 & 2 & 0.642 \\
\hline $\begin{array}{l}\text { Children inherit their language ability from their } \\
\text { parents, it's in their genes }\end{array}$ & 4 & 24 & 45 & 27 & $2.95(0.82)$ & 3 & 3 & 0.191 \\
\hline $\begin{array}{l}\text { Most children do well at reading words in school } \\
\text { because their parent read storybooks at home }\end{array}$ & 52 & 45 & 2 & 1 & $1.52(0.59)$ & 1 & 1 & 0.332 \\
\hline $\begin{array}{l}\text { I think that it is important to develop a broad } \\
\text { interest in reading in my child }\end{array}$ & 47 & 50 & 2 & 1 & $1.57(0.59)$ & 2 & 2 & 0.443 \\
\hline $\begin{array}{l}\text { I think reading books will help my child develop } \\
\text { new vocabulary, thinking, understanding, and } \\
\text { moral values }\end{array}$ & 57 & 41 & - & 2 & $1.47(0.61)$ & 1 & 1 & 0.348 \\
\hline Total score & & & \multicolumn{6}{|c|}{ Mean (SD)/Average score: 29.45 out of total score of 60} \\
\hline Cronbach's alpha & & & 0.672 & & & & & \\
\hline
\end{tabular}

A score of $1=$ Strongly Agree, a score of $2=$ Agree, a score of $3=$ Disagree, a score of $4=$ Strongly Disagree. Scores for this sub-section could range from 15 to 60

Table 5 Correlations between SES, child's age, and HLE variables

\begin{tabular}{lll}
\hline HLE variables & SES & Child's age \\
\hline Age of exposure & $-0.24^{*}$ & 0.05 \\
Number of books read per week & $0.24^{*}$ & 0.18 \\
Number of books read per day & 0.17 & $0.48^{* *}$ \\
Number of books in the home & 0.10 & 0.09 \\
Child's interest in reading & $0.25^{*}$ & $0.47^{* *}$ \\
Parent reading practices & $0.42^{* *}$ & $0.36^{* *}$ \\
Parent attitudes and beliefs & -0.02 & -0.12 \\
\hline
\end{tabular}

*Correlation significant at $\mathrm{p}<0.05$

**Correlation significant at $\mathrm{p}<0.01$ day $\left(r_{s}=0.48, p<0.01\right)$. Further, a weak, positive correlation $\left(r_{s}=0.36, p<0.01\right)$ was noted for parent reading practices.

\section{Discussion}

The present study findings provide preliminary data, previously unavailable, regarding HLE in the Udupi district in Karnataka in southwest India. The following highlights implications of the survey results.

\section{Age and Frequency of Exposure}

A majority of parents reported that they began reading to their children between 2 to 4 years of age. This is generally older than parental reports in studies from other 
geographical locations in which children are read to as early as 6 to 12 months (e.g., Kucirkova et al. 2012; Honig and Shin 2001; Sénéchal et al. 1998; DeBaryshe 1993). However, there is no other data regarding age of exposure in India, so it is speculative to infer why reading is associated with older children in this sample of Indian families. The frequency of exposure to storybooks in this sample was consistent with Kalia (2007) who reported that bilingual, middle-class parents of children from an English private preschool in Bangalore, India read at least one-two times per week (i.e., 61\%) and spent up to ten minutes per day (i.e., $47 \%$ ). Compared to these Indian contexts, a higher reading frequency has been reported by parents in the Western contexts. For instance, Bracken and Fischel (2008) reported that $54 \%$ of parents of the preschool children attending the Head Start program in the United States read daily to their child and $22 \%$ read more than $20 \mathrm{~min}$. In this study, the majority of parents reported reading at least 1-2 times per week (i.e., $61 \%$ ) and spent up to 10 min per day (i.e., $47 \%$ ).

The majority of households in the present study (i.e., $86 \%$ ) had fewer than ten children's books in their home, which is less than reported in Kalia (2007) who found that parents had approximately 22 books in the home. This study and Kalia (2007) report fewer books in the home than studies in other sociocultural contexts. Sénéchal et al. (1998) reported that parents had 61 to 80 children's books in the home and Stephenson et al. (2008) reported that parents had 100-199 books. On the other hand, among the parents in Tehran, Iran, Sajedi et al. (2018) reported that the average number of children books was ten. Taken together, there may be sociocultural and/or environmental factors that impact the number of books in the home. For, example visiting the library for storybook reading is not a common practice in Indian context as compared to Western contexts. DeBaryshe (1993) reported that $75 \%$ of children visited New York libraries. None of the parents in this study reported regular library visits, which is consistent with Kalia (2007). Very often parents buy books from the children book stores or receives as gifts from friends and families. Fewer books in the home may be a contributing factor to lower reading frequency and the late onset of reading exposure in Indian home contexts.

\section{Children's Interest in Reading}

In the present study, parents reported that their children were interested during storybook reading activities, which is similar to observations among middle and low-income community in India made by Kalia and Vagh (2008). However, parents in the present study reported that the children did not always ask for their parents to read to them. This is contrary to Sénéchal et al. (1998) and Bracken and Fischel (2008) findings, indicating that children themselves took the initiative in joint storybook reading. A majority of parents reported that their child asked questions if the story was not clear; however, they did not think that their child could guess what would happen next in the story. It may be that parents did not attempt to provide an opportunity for the child to guess regarding what happens in the rest of the story, which made it the least reported behavior in the current study. Additionally, a majority of parents reported that their child sometimes or never read along with them. It may be that parents did not expect their child to read along so they did not provide an opportunity to their child. In consonance with this finding, the position paper on early language and literacy (2016) documents that the children in this age band are often considered to be 'not ready' to learn to read and write.

\section{Storybook Reading Practices and Attitudes and Beliefs About Storybook Reading}

Parents were using some critical strategies and utilized reading practices consistent with language and literacy. Parents exhibited storybook reading practices that contribute to language and literacy skills. For example, parents reported that they named and talked about pictures in books, pointed their children's fingers to pictures/words/letters, and asked questions, all of which are consistent with positive practices in other studies (e.g., Aram and Shapira 2012; DeBaryshe and Binder 1994; Mol et al. 2008). However, some practices were not identified by a majority of parents (e.g., making up their own stories and encouraging the child to make their own story). It may be that parents are doing other behaviors that were not captured in this survey. For example, in Indian homes, parents engage children in the oral tradition of storytelling which has developed as a folk art in India (Buvaneswari and Padakannaya 2017; Kalia and Vagh, 2008; Khurana and Rao 2011; Sheoran 1975). Presence of grandparents and elders in children's home environment further enriches the use of oral story telling practices.

Reading beliefs are portrayed as parental assumptions regarding reading to their children and their capacity to go about as an educator to their child, their self-efficacy when reading to their child, and the available materials (DeBaryshe 1995). In this study, a majority of parents have positive attitudes and beliefs about reading and perceive that they have a role in reading. For example, they reported that storybook reading will help their child in grasping new words and learn to read new words at school. Parents indicated that they enjoyed reading with their children. This parental perspective is in consonance with Weigel et al.'s (2006) description of facilitative parents who enjoy reading to their child and report having good memories of reading in their childhood. Interestingly, parents in this sample reported that they believe that their children were not too young to learn about reading, which is not congruent with 
the reported age of exposure. Overall, findings suggest that parents were aware of the benefits of storybook reading and reported a positive attitude towards this experience.

\section{Association of SES, Children's Age, and HLE}

The correlation findings indicate that the homes characterized with higher SES included more quality HLE factors such as better storybook reading practice (moderate correlation), greater child's interest towards reading (weak correlation), and reading frequently at a young age (weak correlation). Interestingly, age of exposure was negatively correlated with SES (weak correlation). Overall, these observations suggest that SES is not very strongly associated with HLE variables. These results are consistent with previous studies (e.g., Gottfried et al. 2015; Kalia 2007; Niklas et al. 2016). Further, the demographic variable of child's age was found to correlated with frequency of exposure (i.e., number of books read per day), in that the older the child, the more frequently parents read to their child. Parents' report of interest and engagement in reading practices was associated with older children. This may be linked to the belief that some parents agreed or strongly agreed (i.e., 11\%) that their child is too young to learn about reading. Contrary to previous studies (Bingham 2007; DeBaryshe 1995), the results however suggested that the parental attitude and beliefs about story book reading did not correlate with the demographic variables of SES and child's age. This indicates that the parental attitude and beliefs were strong towards storybook reading regardless of child's age or socioeconomic strata.

\section{Relevance of the Study Findings in the International Context}

The study findings calls attention to the need to understand the nature of HLE from very young age prior to formal schooling. The observations from the Indian context indicate that the focus towards literacy and storybook reading practices in the early childhood may not be following a similar path as documented in the western context. The immersion in literacy environment from birth as noted in the middle class western context may not be applicable globally. More research is therefore warranted in non-western contexts to gain deeper understanding of the sociocultural influences of shared book reading for young children. Further, greater attention is needed for the communities where shared book reading is not considered as an established practice from very young age.

\section{Limitations and Future Directions}

While this survey provides preliminary insight into the HLE in Indian home contexts, it has several limitations and points to future studies. A researcher administered this questionnaire in home or community settings. Use of a parent questionnaire in the presence of the researcher could have led to potential bias due to the social desirability of the responses (Scarborough and Dobrich 1994). Additionally, convenience sampling was used which is not representative of the entire population may have led to sampling bias. The formal assessment of parents' and children's health status and the parents' use of electronic media for reading were not considered in this study and should be explored in future studies. Further, the study focused on the quantity of storybook reading experiences, rather than the quality of the experiences in terms of parent-child interaction behaviors during storybook reading. Future work should describe Indian parent behavior during book reading and examine relationships with children's language and literacy development. There is a need for employing semi-structured interviews to further understand the parental perception of their child's interest in reading and reading practices. Future research focusing on adult-child interaction patterns during storybook reading in both typically developing children and children with language and literacy difficulty will help further understand the nature of the HLE. Future research should consider the influence of different aspects of the HLE on child outcomes in India. For example, predictive relationships between HLE factors and children's language and literacy would provide needed insight. Finally, this study indicated that Indian parents exhibit beliefs, attitudes, and practices associated with a positive HLE. However, the survey may have failed to capture other enriching aspects of the HLE (e.g., storytelling). This may in part explain the later age of exposure to storybook reading. It may be that parents are telling stories to their younger children, rather than reading books.

\section{Conclusion}

The findings of this study provide preliminary information regarding HLE in Indian homes. Findings point toward socioeconomic and sociocultural variation. Of note, Indian parents in this sample initiated storybook reading to their children after 2 years of age than parents from other contexts, wherein reading was initiated even before 1 year of age. The older their children, the more frequently parents engaged in storybook reading. Indian parents in this 
sample read less frequently to their children and had fewer books in the home than parents from other contexts. That said, parents reported that their children were interested in storybook reading and reported the use of quality storybook reading practices. Further, parental attitude and beliefs towards storybook reading did not correlate with the considered demographic variables (i.e., child's age, socioeconomic strata). Understanding more about the parental practices, attitudes and beliefs surrounding storybook reading will facilitate the development of parent programs to enhance and promote quality HLE in Indian home contexts. The findings corroborates with the 2016 position paper on encouraging opportunities for early language and literacy activities in the home environment for pre-primary children between 3 and 6 years of age. This will help in alleviating the challenges faced by young children while transitioning to print based learning in school. This paper therefore calls for more attention towards emphasizing the practice of reading storybooks in Indian households.

Supplementary information The online version of this article (https:// doi.org/10.1007/s10643-020-01147-0) contains supplementary material, which is available to authorized users.

Funding Open access funding provided by Manipal Academy of Higher Education, Manipal.

Open Access This article is licensed under a Creative Commons Attribution 4.0 International License, which permits use, sharing, adaptation, distribution and reproduction in any medium or format, as long as you give appropriate credit to the original author(s) and the source, provide a link to the Creative Commons licence, and indicate if changes were made. The images or other third party material in this article are included in the article's Creative Commons licence, unless indicated otherwise in a credit line to the material. If material is not included in the article's Creative Commons licence and your intended use is not permitted by statutory regulation or exceeds the permitted use, you will need to obtain permission directly from the copyright holder. To view a copy of this licence, visit http://creativecommons.org/licenses/by/4.0/.

\section{References}

Annual Status of Education Report (Rural). (2019). New Delhi (Released January 14, 2020). Retrieved 2 Dec 2020 from http:// img.asercentre.org/docs/ASER\%202019/ASER2019\%20rep ort $\% 20 /$ nationalfindings.pdf.

Aram, D., \& Shapira, R. (2012). Parent-child shared book reading and children's language, literacy, and empathy development. Rivista Italiana di Educazione Familiare, 7(2), 55-65 https://oaj.fupre ss.net/index.php/rief/article/download/4073/4073

Bingham, G. E. (2007). Maternal literacy beliefs and the quality of mother-child bookreading interactions: Associations with children's early literacy development. Early Education and Development, 18(1), 23-49. https://doi.org/10.1080/10409280701274428.

Bojczyk, K. E., Davis, A. E., \& Rana, V. (2016). Mother-child interaction quality in shared book reading: Relation to child vocabulary and readiness to read. Early Childhood Research Quarterly, 36, 404-414. https://doi.org/10.1016/j.ecresq.2016.01.006.

Bracken, S. S., \& Fischel, J. E. (2008). Family reading behavior and early literacy skills in preschool children from low-income backgrounds. Early Education and Development, 19(1), 45-67. https ://doi.org/10.1080/10409280701838835.

Bus, A. G., Leseman, P. P., \& Keultjes, P. (2000). Joint book reading across cultures: A comparison of Surinamese-Dutch, Turkish-Dutch, and Dutch parent-child dyads. Journal of Literacy Research, 32(1), 53-76. https://doi.org/10.1080/1086296000 9548064.

Buvaneswari, B., \& Padakannaya, P. (2017). Development of a home literacy environment questionnaire for tamil-speaking kindergarten children. Language Testing in Asia, 7(1), 1-15. https://doi. org/10.1186/s40468-017-0047-y.

Census of India. (2011). Provisional population totals. Retrieved 19 Nov 2020 from https://censusindia.gov.in/2011-prov-results/paper 2/data_files/india/paper2_1.pdf.

Centre for Early Childhood Education and Development (CECED) and CARE India. (2016). Early literacy and language in India: A position paper, New Delhi. Retrieved 19 Nov 2020 from https://www. careindia.org/wp-content/uploads/2017/05/ELL-English-2.pdf.

Chang, C. J., \& Luo, Y. H. (2020). A longitudinal study of maternal interaction strategies during joint book-reading in Taiwan. Journal of Child Language, 47(2), 401-417. https://doi.org/10.1017/ S0305000919000746.

Christian, K., Morrison, F. J., \& Bryant, F. B. (1998). Predicting kindergarten academic skills: interactions among child care, maternal education, and family literacy environments. Early Childhood Research Quarterly, 13(3), 501-521. https://doi.org/10.1016/ S0885-2006(99)80054-4.

Debaryshe, B. D. (1993). Joint picture-book reading correlates of early oral language skill. Journal of Child Language, 20(2), 455-461. https://doi.org/10.1017/S0305000900008370.

DeBaryshe, B. D. (1995). Maternal belief systems: Linchpin in the home reading process. Journal of Applied Developmental Psychology, 16(1), 1-20. https://doi.org/10.1016/0193-3973(95)90013-6.

Debaryshe, B. D., \& Binder, J. C. (1994). Development of an instrument for measuring parental beliefs about reading aloud to young children. Perceptual and Motor Skills, 78(3), 1303-1311. https:// doi.org/10.2466/pms.1994.78.3c.1303.

DeBruin-Parecki, A. (1999). Assessing adult/child storybook reading practices. CIERA Report. https://files.eric.ed.gov/fulltext/ED447 412.pdf

DeVellis, R. F. (2016). Scale development: Theory and applications (Vol. 26). Los Angeles: Sage publications.

Gottfried, A. W., Schlackman, J., Gottfried, A. E., \& Boutin-Martinez, A. S. (2015). Parental provision of early literacy environment as related to reading and educational outcomes across the academic lifespan. Parenting, 15(1), 24-38. https://doi.org/10.1080/15295 192.2015.992736.

Government of India, Planning Commission. (2010). Evaluation Report on Sarva Shiksha Abhiyan. Retrieved 19 Nov 2020 from http://planningcommission.nic.in/reports/peoreport/peoevalu/ peo_ssa2106.pdf.

High, P. C., Klass, P., Donoghue, E., Glassy, D., DelConte, B., Earls, M., et al. (2014). Literacy promotion: An essential component of primary care pediatric practice. Pediatrics, 134(2), 404-409. https ://doi.org/10.1542/peds.2014-1384.

Honig, A. S., \& Shin, M. (2001). Reading aloud with infants and toddlers in child care settings: An observational study. Early Childhood Education Journal, 28(3), 193-197. https://doi. org/10.1023/A:1026551403754.

Justice, L. M., \& Ezell, H. K. (2000). Enhancing children's print and word awareness through home-based parent intervention. American Journal of Speech-Language Pathology, 9, 257-269. 
Kalia, V. (2007). Assessing the role of book reading practices in Indian bilingual children's English language and literacy development. Early Childhood Education Journal, 35(2), 149-153. https://doi. org/10.1007/s10643-007-0179-2.

Kalia, V., \& Reese, E. (2009). Relations between Indian children's home literacy environment and their English oral language and literacy skills. Scientific Studies of Reading, 13(2), 122-145. https ://doi.org/10.1080/10888430902769517.

Kalia, V., \& Vagh, S. B. (2008). Home literacy environments of young Indian Children from middle-and low-socioeconomic backgrounds. In: R. T. Waddell \& R. M. McBride (Eds.) New Research in Early Childhood Education (pp. 11-34), Nova Science Publishers.

Kaul, V., Bhattacharjea, S., Chaudhary, A. B., Ramanujan, P., Banerji, M., \& Nanda, M. (2017). The India early childhood education impact study. New Delhi: UNICEF. Accessed 19 Nov 2020.

Khurana, S., \& Rao, P. K. (2011). Emergent literacy experiences in the classroom-A sample survey in Mysore City. Language in India, 11(3). Retrieved from http://www.languageinindia.com/ march2011/sarikapremaemergentliteracyfinal.pdf.

Kluczniok, K., Lehrl, S., Kuger, S., \& Rossbach, H. G. (2013). Quality of the home learning environment during preschool ageDomains and contextual conditions. European Early Childhood Education Research Journal, 21(3), 420-438. https://doi. org/10.1080/1350293X.2013.814356.

Kucirkova, N., Messer, D., \& Whitelock, D. (2012). Parents reading with their toddlers: The role of personalization in book engagement. Journal of Early Childhood Literacy, 13(4), 445-470. https ://doi.org/10.1177/1468798412438068.

Mol, S. E., \& Bus, A. G. (2011). To read or not to read: A meta-analysis of print exposure from infancy to early adulthood. Psychological Bulletin, 137(2), 267-296. https://doi.org/10.1037/a0021890.

Mol, S. E., Bus, A. G., de Jong, M. T., \& Smeets, D. J. H. (2008). Added value of dialogic parent-child book readings: A metaanalysis. Early Education and Development, 19, 7-26. https:// doi.org/10.1080/10409280701838603.

Neuman, S. B. (1996). Children engaging in storybook reading: The influence of access to print resources, opportunity, and parental interaction. Early Childhood Research Quarterly, 11(4), 495-513. https://doi.org/10.1016/S0885-2006(96)90019-8.

Neumann, M. M. (2016). A socioeconomic comparison of emergent literacy and home literacy in Australian preschoolers. European Early Childhood Education Research Journal, 24(4), 555-566. https://doi.org/10.1080/1350293X.2016.1189722.

Newland, L. A., Gapp, S. C., Jacobs, G. M., Reisetter, M. F., Syed, D. C., \& Wu, C.-H. (2011). Mothers' beliefs and involvement: Links with preschool literacy development. International Journal of Psychology: A Biopsychosocial Approach, 9, 67-90.

Niklas, F., Cohrssen, C., \& Tayler, C. (2016). The sooner, the better: Early reading to children. Sage Open, 6(4), 2158244016672715. https://doi.org/10.1177/2158244016672715.

Niklas, F., Wirth, A., Guffler, S., Drescher, N., \& Ehmig, S. C. (2020). The home literacy environment as a mediator between parental attitudes toward shared reading and children's linguistic competencies. Frontiers in Psychology, 11, 1628. https://doi. org/10.3389/fpsyg.2020.01628

Ninio, A., \& Bruner, J. (1978). The achievement and antecedents of labelling. Journal of Child Language, 5(1), 1-15. https://doi. org/10.1017/S0305000900001896.

O'Farrelly, C., Doyle, O., Victory, G., \& Palamaro-Munsell, E. (2018). Shared reading in infancy and later development: Evidence from an early intervention. Journal of Applied Developmental Psychology, 54, 69-83.

Pezoa, J. P., Mendive, S., \& Strasser, K. (2019). Reading interest and family literacy practices from prekindergarten to kindergarten: Contributions from a cross-lagged analysis. Early Childhood Research Quarterly, 47, 284-295. https://doi.org/10.1016/j.ecres q.2018.12.014.

Raikes, H., Alexander Pan, B., Luze, G., Tamis-LeMonda, C. S., Brooks-Gunn, J., Constantine, J., et al. (2006). Mother-child book reading in low-income families: Correlates and outcomes during the first three years of life. Child Development, 77(4), 924-953. https://doi.org/10.1111/j.1467-8624.2006.00911.x.

Sajedi, F., Habibi, E., Hatamizadeh, N., Shahshahanipour, S., \& Afzali, H. M. (2018). Early storybook reading and childhood development: A cross-sectional study in Iran. F1000Research. https://doi. org/10.12688/f1000research.14078.1.

Saleem, S. M. (2019). Modified Kuppuswamy socioeconomic scale updated for the year 2019. Indian Journal of Forensic and Community Medicine, 6(1), 1-3. https://doi.org/10.18231 /2394-6776.2019.0001.

Scarborough, H. S., \& Dobrich, W. (1994). On the efficacy of reading to preschoolers. Developmental Review, 14(3), 245-302. https:// doi.org/10.1006/drev.1994.1013.

Sénéchal, M., \& LeFevre, J. (2002). Parental involvement in the development of children's reading skill: A 5-year longitudinal study. Child Development, 73, 445-460. https://doi.org/10.1111/14678624.00417.

Sénéchal, M., LeFevre, J. A., Hudson, E., \& Lawson, E. P. (1996). Knowledge of storybooks as a predictor of young children's vocabulary. Journal of Educational Psychology, 88(3), 520-536. https://doi.org/10.1037/0022-0663.88.3.520.

Sénéchal, M., Lefevre, J. A., Thomas, E. M., \& Daley, K. E. (1998). Differential effects of home literacy experiences on the development of oral and written language. Reading Research Quarterly, 33(1), 96-116. https://doi.org/10.1598/RRQ.33.1.5.

Sharma, S., \& Saini, S. (2000). Influence of social stratification, occupation and income of the parents on the home environment of preschoolers. Asian Journal of Psychology and Education, 33(5/6), $11-17$.

Sheoran, K. (1975). Contemporary children's literature in India. Children's Literature, 4(1), 127-137.

Stephenson, K. A., Parrila, R. K., Georgiou, G. K., \& Kirby, J. R. (2008). Effects of home literacy, parents' beliefs, and children's task-focused behavior on emergent literacy and word reading skills. Scientific Studies of Reading, 12(1), 24-50. https://doi. org/10.1080/10888430701746864.

Weigel, D. J., Martin, S. S., \& Bennett, K. K. (2006). Mothers' literacy beliefs: Connections with the home literacy environment and pre-school children's literacy development. Journal of Early Childhood Literacy, 6(2), 191-211. https://doi.org/10.1177/14687 98406066444.

Zhou, H., \& Salili, F. (2008). Intrinsic reading motivation of Chinese preschoolers and its relationships with home literacy. International Journal of Psychology, 43(5), 912-916. https://doi. org/10.1080/00207590701838147.

Publisher's Note Springer Nature remains neutral with regard to jurisdictional claims in published maps and institutional affiliations. 